\title{
透過音の主観評価に関する実験的検討 \\ EXPERIMENTAL STUDY ON SUBJECTIVE EVALUATION OF SPEECH SOUND THROUGH WALLS
}

\author{
宮尾健 一*1, 大川 平一郎*2, 山崎芳男*3 \\ Ken-ichi MIYAO, Heiichiro OHKAWA and Yoshio YAMASAKI
}

\begin{abstract}
This study investigates evaluation of speech sound through walls. In this case, it is nesessary to consider the effects of background noise. This paper describes the results of subjective evaluation in different background noise level.

The results of this paper are as follows;

1. Transmitted speech sound level is better for index of this purpose than sound pressunre level difference.

2. Level difference between transmitted speech sound level and background noise level is related to the results of subjective evalution.
\end{abstract}

Keywords: sound insulation, sound pressure level difference, transmitted speech sound level,

background noise level,word detection, word intelligibility

遮音、室間平均音圧レベル差、透過音レベル、背景音レベル、単語検知、単語了解度

1.はじめに

集合住宅、ホテルなどの居室では、隣室（戸）から話し声が聞 こえるといった事象による音響的障害の発生は決して少なくない ことを経験している。このような事象へは、いままで、両室間の 遮音性能を表す室間平均音圧レベル差の值で対応してきた。この 室間平均音圧レベル差は、物理的な尺度として遮音設計性能評価 には使用実績があるが、入居者・利用者からの主観的な判断であ る苦情との対応については十分なものであるとはいえない。この 主観的な判断は、透過音が検知できる、内容が認識できる、ま た、その音量感、音質感、不快感なども関係し、生活実感として の透過音に対する評価には、物理的な尺度である室間平均音圧レ ベル差ではない別の尺度が必要である。物理的尺度としての室間 平均音圧レベル差は、壁構造の透過損失、透過面積、受音室の等 価吸音面積（吸音力）、対象壁構造以外からの側路伝搬音が寄与 し決定されるものであり、背景音の要素は入らない。

今回の検討は、この透過音を単に物理的な值として評価するの ではなく、背景音の影響も含め、音声の検知、認知、すなわち 「聞こえ方」、「了解度」という視点から室間の遮音性能を評価 することを試み、最終的には、隣接室からの透過音を生活実感に 近い形での単一数值による評価をする方法を提案することを目的
としている。

\section{2. 実験方法}

\section{1 音声伝送場の物理的条件}

音源室から受音室への音声の伝送には、図 1 に示したような伝 送系が考えられる。したがって、音源である音声は、まず音源室 の物理的条件としての吸音、反射、残響、また背景音の影響を受 け、壁・床を透過する段階で大きく減衰する。受音室に透過した 音は、音源室と同様に、物理的条件の影響を受けた後に受聴者に 検知あるいは認知される。この検知・認知されるまでの過程に生 じる物理的条件のうち、壁構造、室内の吸音条件を可変設定する ことの出来る実験室（コンクリート造）を用いて、表 1 に示した 遮音特性を有する 5 種類の壁構造について、主観評価実験用音源 作成のための基礎資料として、2 室間の室間平均音圧レベル差及 びインパルスレスポンスを求めた。

\section{2 主観評価実験}

1) 主観評価実験システム 主観評価実験システム注1) を図 2 に示した。この実験システム と図 1 に示した音声の伝送模式図との関連などについて次に述べ
*1 戸田建設(侏技術研究所

*2 侏音環境研究所所長. 工博

*3 早稲田大学理工総研音響情報研究室 教授. 工博
Technical Research Institute, Toda Corp.

Sound Environment Research Inc., Dr. Eng.

Prof., Acoustic Laboratory, Advanced Research Center for Science and Engineering, Waseda University, Dr. Eng. 
る。

ここでは、図 1 の音源側・受音側での背景音と、空・扉等から の側路伝搬音は含まれないインパルスレスポンスを考える。

まず、インパルスレスポンス測定用信号(M系列ノイズ)が2.1 で述べた音源側実験室内で放射され、表 1 に示した試験壁を透過 し、受音側実験室内の受音点に到達するまでの上記を除く全ての 音響的な情報は、「音源 $\rightarrow$ 受音点」のインパルスレスポンスに含 まれているとの前提条件に立っている。このインパルスレスポン スとドライソースを骨込み実音化し、無響室の受聴点で被験者に 呈示することにより、試験壁を透過した音声を受聴点で擬似的に 聴取しているとの考え方をしている。

ただし、インパルスレスポンスは、実験室内の背景音の影響を 出来るたけ受けないようにスピーカの出力を調整し、かつスピー カ 1 力所・受音点 1 力所で測定したものである。したがって、室 間平均音圧レベル差・室内平均吸音率から、受音室における音声 の平均的なオクターブバンドレベルを別に計算により求めておく 必要がある。主観評価実験にあたっては、各条件毎の受音室にお けるオクターフバンドレベル計算値と被験者位置の受聴点オク

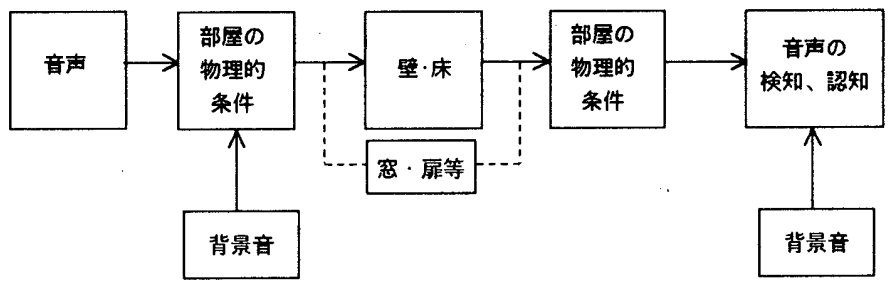

図 1 音声の伝送模式図

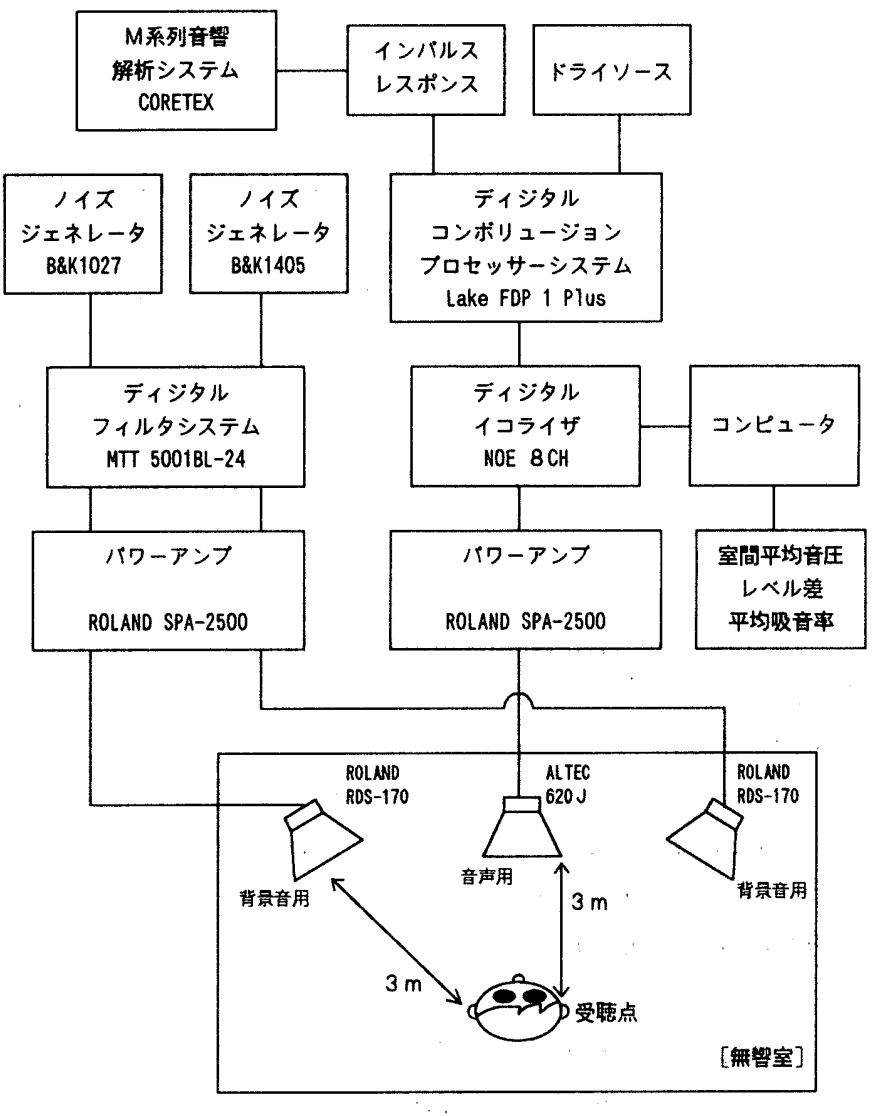

図2 主観評価実験システム

表 1 壁構造と遮音特性パターン、透過音特性パターン

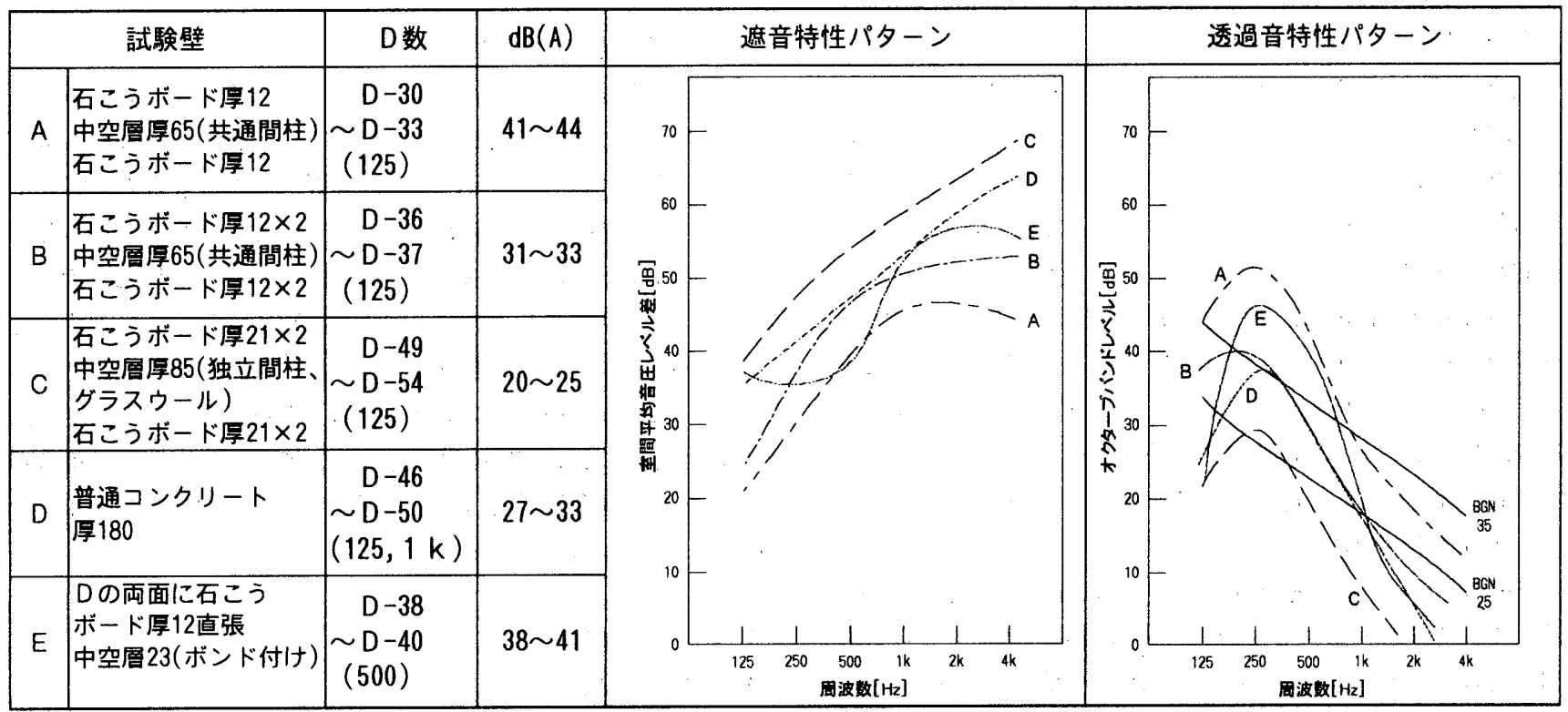

注 1) 音源側実験空、受音側実験室の吸音条件を、それぞれ、反射性 : $\mathrm{R}\left(500 \mathrm{~Hz}\right.$ の吸音率 $\bar{\alpha}_{500}=0.08$ )、吸音性: $\mathrm{A}$ (同; $\left.\bar{\alpha}_{500}=0.15\right)$ の 2 通 りとし、壁構造毎に、音源室 $\rightarrow$ 受音室の条件を 4 通り $(R \rightarrow R 、 R \rightarrow A 、 A \rightarrow R 、 A \rightarrow A) に$ 設定した。

注 $2 ） \mathrm{D}$ 数は、室間平均音圧レベル差に関する遮音等級の基淮周波数特性をもとにして、1 $\mathrm{dB}$ ステップで求めた遮音等級である。（）内は $\mathrm{D}$ 数を 決定する周波数帯域（Hz) である。

注 3 ）透過音レベル $\mathrm{dB}(\mathrm{A})$ は、壁構造を透過し受音室に到達した音声のピークレベル（動特性:FAST）の計算值である。

注 4 ) 透過音特性パターン中に、呈示する背景音 (BGN) のうち、例として25、35dB(A)の特性パターンを示した。 
ターブバンドレベルを一致させるように、コンピュータで制御し ている。

また、インパルスレスポンスは、信号を対象壁に垂直入射させ た条件でのものであり、音声の入射条件がこの条件に限られた実 験となる。

今回の実験の主な目的である被験者への背景音の呈示は、一般 的な場合は図 1 における音源側の背景音の影響を考えなくてもよ いものとして、受音側のみを対象とし、四 2 に示したように、音 声呈示用のシステムとは別に、背景音呈示用のシステムから直接 被験者に呈示する方法とし、定常的な環境騒音を模擬した特性と した。

\section{2 ）主観評価実験用音声の作成}

主観評価実験に使用する音源用の文章は、まず「形容詞＋名詞十 動詞」より成る文章で、被験者に類推、記憶されることの少ないこ とを念頭に、表 2 に示したような脈絡のない実験用文章1) 4) の 音表を作成した。このとき、辞書からピックアップした形容詞、 名詞、動詞を無作為に組合わせて文章を作成し、適切なものだけ を選択し、音表間に特徵の出ないように調整を行った。なお、 1 音表は50文で構成されている。

これらの音表を、無響室内で女性ナレーターによって読みあげ てもらい収録し、実験用音声（ドライソース）を作成した。さら に、表 1 で示した物理的条件下で測定したインパルスレスポンス に実験用音声を畳込み、主観評価実験用音源としての音声とし た。なお、ドライソースは文頭から文頭までを10Sとした。した がって、1 音表の呈示時間は $500 \mathrm{~S}$ となる。

\section{3 ）主観評価実験}

主観評価実験は無響室で行い、聞こえ方のグレード」「単語了 解度」を尺度とした測定を、1）で述べた実験システムを用いて 行った。

音源のレベルとしては、罒 3 に示した音声のパワーレベルを用 い、ピークレベル79dB (A) [動特性 : FAST］に設定した。受音室 における透過音のレベルは、このパワーレベルを用い、1）で述 べたように、表 1 に示した壁構造の遮音特性と吸音条件毎に計算 によって求めた。被験者への透過音の呈示は、設定実験条件にし たがって、被験者の前面 $3 \mathrm{~m}$ の位置に設置した試験用音声呈示用 スピーカより、1 条件について 1 音表を呈示し、聞こえ方」のグ レードとして、「聞こえる（A）」「かすかに聞こえる（B）」「聞 こえない（C）」の三者択一で被験者に回答させた。また、その 結果に A:1.0、B:0.5、C:0のポイントを与え点数化した。「単 語了解度」の場合には、脈絡のない試験用文章の「名詞」のみを 筆記回答させて、その正答率を算出した。なお、透過音のレベル は、表 1 に示したように $20 \mathrm{~dB}(\mathrm{~A}) \sim 44 \mathrm{~dB}(\mathrm{~A})$ の範囲にある。

また、背景音レベルは、25、30、35、40、45dB (A)とし、その 周波数特性は、表 1 に例を示したように、実測値からほぼオク ターブ $5 \mathrm{~dB}$ 下がりの特性に設定した。背景音は、スピーカを 2 個 用いて、無相関ノイズを試験用音声呈示用スピーカの両サイドか ら被験者に呈示した。
表 2 音表の例

\begin{tabular}{|c|c|c|c|}
\hline \multicolumn{4}{|c|}{ 音衰その5 } \\
\hline 1 & 黒い & 電文が & すべる \\
\hline 2 & しとやかな & 時嘲が & ひらめく \\
\hline 3 & 若い & 煙が & 映える \\
\hline 4 & あさやかな & 酸素が & 倒れる \\
\hline 5 & 強い & m m & たくらむ \\
\hline 6 & 柔らかい & 眼鏡が & 者える \\
\hline$\cdot$ & $\cdot$ & $\cdot$ & · \\
\hline$\cdot$ & $\cdot$ & - & $\cdot$ \\
\hline 44 & 重い & 景色が & はがす \\
\hline 45 & まぶしい & くじらが & すわる \\
\hline 46 & もろい & 小川が & 乘る \\
\hline 47 & のどかな & 刀が & つまる \\
\hline 48 & 利口な & ふとんが & 浴びる \\
\hline 49 & あたたかい & 橋が & 怒る \\
\hline 50 & くやしい & 㚼が & 溶ける \\
\hline
\end{tabular}

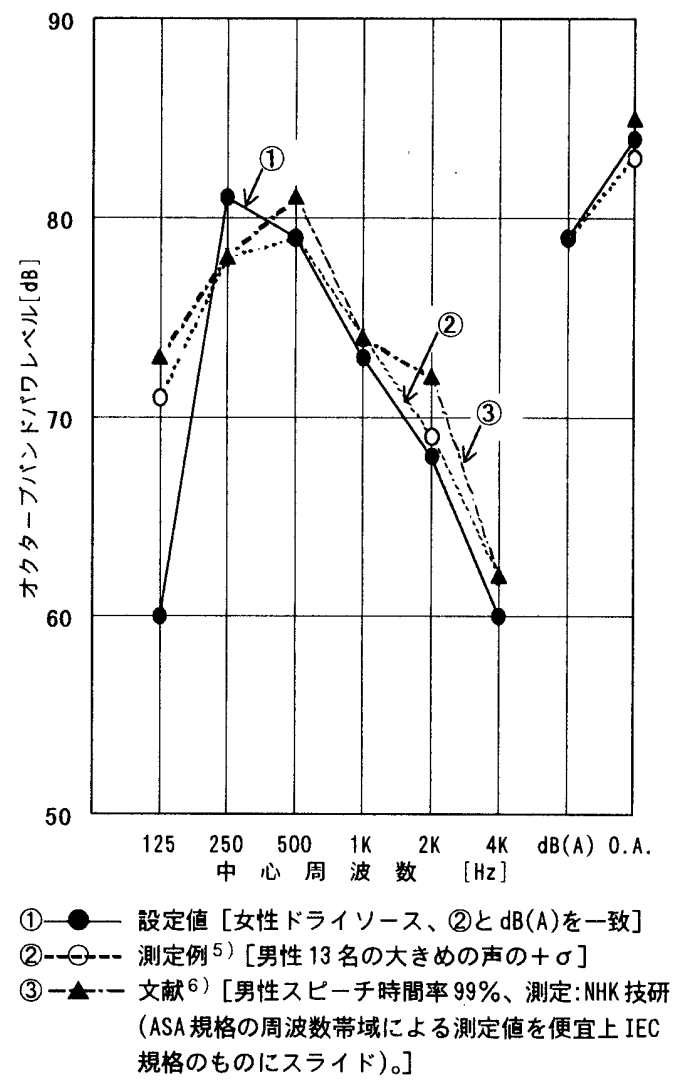

図 3 人声のパワーレベル設定值

被験者は、正常な聴力を有する20代〜 50代の男性 5 名、女性 3 名計 8 名である。

\section{3. 主観評価実験結果の検討 I}

\subsection{D数と聞こえ方、単語了解度}

背景音レベルをパラメーターとし、室間平均音圧レベル差より 求めた $\mathrm{D}$ 数と、聞こえ方のグレードとの関係を図 4 に、単語了解 度との関係を図 5 に示した。図 4 から次のことがわかった。

(1) 背景音レベルが $25 \mathrm{~dB}(\mathrm{~A}) \sim 40 \mathrm{~dB}(\mathrm{~A})$ の範囲では、相関係数が 
0.75〜0.82を示し、 $45 \mathrm{~dB}(\mathrm{~A})$ のときはさらに相関 係数が小さくなる。

(2) グレードが 0.5 (かすかに聞こえる)以下と なる D 数の值は、背景音レベルが $25 \mathrm{~dB}(\Lambda)$ のと きで D-53以上、 $40 \mathrm{~dB}(\mathrm{~A})$ のときで D-41以上で ある。この範囲では、背景音レベルが $5 \mathrm{~dB}$ 大き くなると、D数の值は 3 〜 小さい值となる。 ただし、背景音レベルが45dB（A)のときは傾向 が異なる。

また、図 5 から次のことがわかった。

(1) 背景音レベルが25dB(A)のときは、相関係数は 0.90を示したが、30dB $(A) 〜 40 \mathrm{~dB}(\mathrm{~A})$ では0.64〜

0.75 を示し、 $45 \mathrm{~dB}(\mathrm{~A})$ のときはさらに相関係数が 小さくなる。

(2) 意味がわからなくなる領域は、D数の值が、 背景音レベルが25dB（A)のときでD -52以上、 $40 \mathrm{~dB}(\mathrm{~A})$ のときで D -50以上であり、この範囲で のD数の値の差は小さい。また、背䀠音レベル が45dB(A)のときは、D-40以下でも意味のわか らなくなるケースがある。

D 数と主観評価量が強い相関を示さなかった 理由としては、次のようなことが考えられる。

D数を決定する周波数帯域は、裴1に示した ように、試験壁 A、B、Cのボード壁では $125 \mathrm{~Hz}$ 、試験壁 D のコンクリート壁では $125 \mathrm{~Hz}$ 、

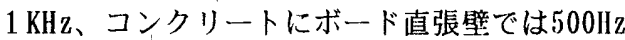
となっているのに対し、透過音特性パターンに 示したように、透過音の周波数特性は、全ての 試験壁で、250Hz帯域が卓越している。このた め、D数の場合には、被験者が判断している周 波数帯域と「ズレ」を生じていることが強い相 関を示さない原因であると推察される。

\section{2 透過音レベルと聞こえ方、単語了解度}

ここでは、背景音レベルをパラメーターと

し、透過音レベルを指標として検討する。

透過音レベルと、聞こえ方のグレードとの関 係を図 6 に、単語了解度との関係を図 7 に示し た。図 6 から次のことがわかった。

(1) 背景音レベルが $25 \mathrm{~dB}(\mathrm{~A}) \sim 45 \mathrm{~dB}(\mathrm{~A})$ で、相関 係数は0.90以上を示した。ただし、透過音しべ ルが $20 \mathrm{~dB}(\mathrm{~A})$ と小さいときは、回帰直線から

「聞こえない」側に外れる。

(2) 聞こえ方のグレードが0.5以下となる透過音 レベルの值は、背景音レベルが $25 \mathrm{~dB}(\mathrm{~A})$ のとき で23dB(A)以下、35dB(A)のときで28dB(A)以下で あり、この範囲では、背景音レベルが $5 \mathrm{~dB}$ 大き くなると、この透過音レベルは $2 \sim 3 \mathrm{~dB}$ 大きく

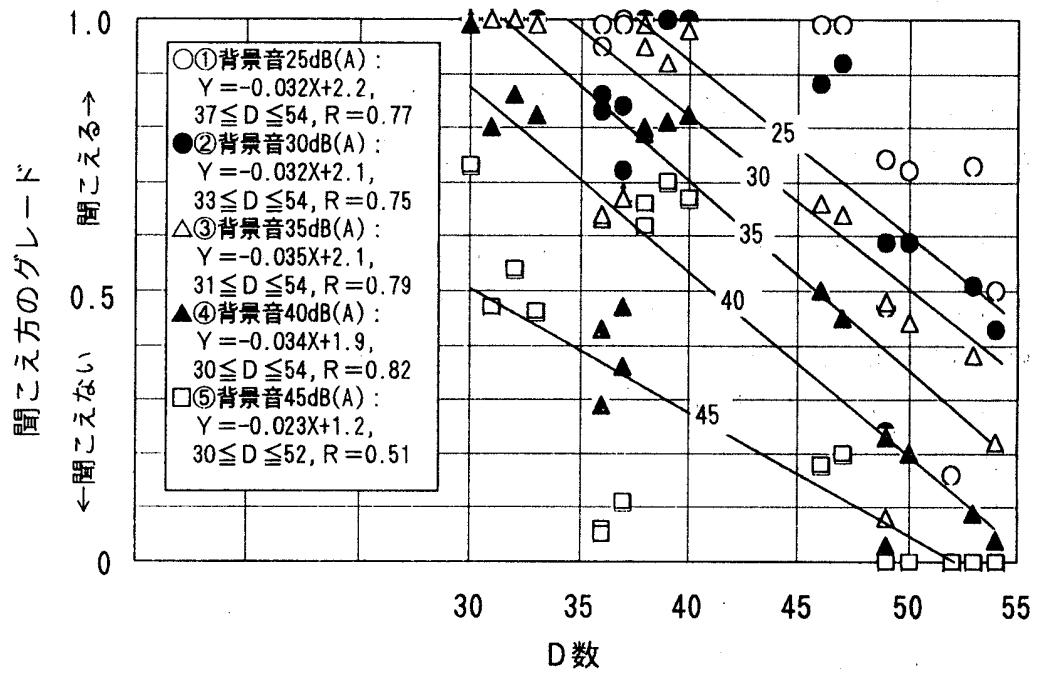

図4D数と聞こえ方のグレード

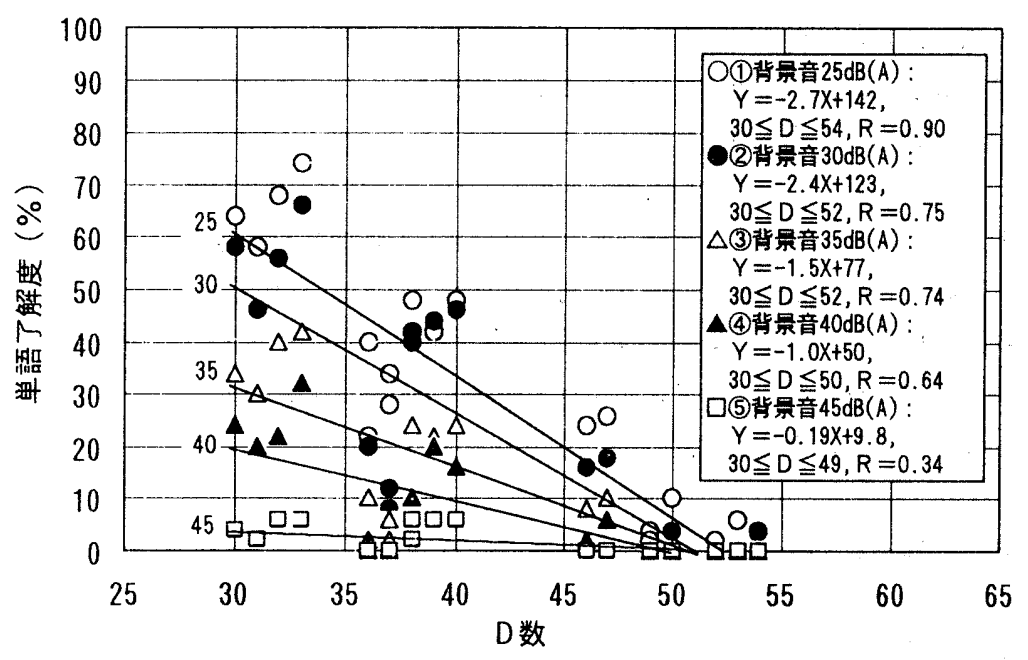

図 5 D数と単語了解度

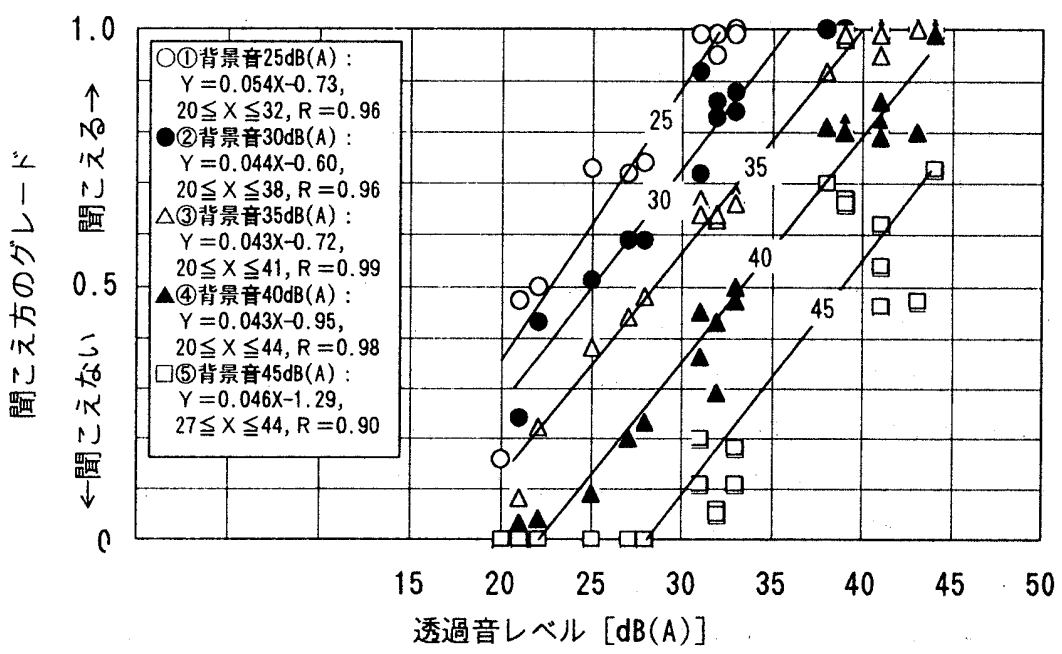

図6 透過音レベルと聞こえ方のグレード 
なる。また、背景音レベルがこれ以上になる と、この透過音レベルの変化量は大きくなり、 傾向が異なってくる。

また、図 7 から次のことがわかった。

(1) 背景音レベルが $25 \mathrm{~dB}(\mathrm{~A}) \sim 40 \mathrm{~dB}(\mathrm{~A})$ では、相 関係数は 0.85 以上を示したが、 $45 \mathrm{~dB}(\mathrm{~A})$ のとき は相関係数は小さくなる。

(2) 意味がわからなくなる領域は、透過音レべ ルの值が、背景音レベルが $25 \mathrm{~dB}(\mathrm{~A})$ のときで $23 \mathrm{~dB}(\mathrm{~A})$ 以下、35dB(A)のときで $29 \mathrm{~dB}(\mathrm{~A})$ 以下で あり、この範囲では、背景音レベルが $5 \mathrm{~dB}$ 大き くなると、この透過音レベルの值は $3 \mathrm{~dB}$ 大きく なる。

透過音レベルの方か、 $\mathrm{D}$ 数よりも主観評価量 と強い相関を示す理由としては、次のようなこ とが考えられる。

表 1 の透過音特性パターンで示したように、 透過音の卓越周波数は $250 \mathrm{~Hz}$ 帯域であるが、こ のオクターブバンドレベルは $\mathrm{dB}(\mathrm{A})$ 值に大きく 寄与している（試験壁によっては、500Hz带域 も寄与）。さらに、図 3 で示したように人声の パワレベルは $250 \mathrm{~Hz} 、 500 \mathrm{~Hz}$ 帯域が卓越してい る。このため、透過音レベルの場合には、3.1で 述べたような被験者が判断している周波数帯域 との「ズレ」を生じにくいことが強い相関を示 す原因であると推察される。

\section{4. 主観評価実験結果の検討 II}

検討 I の結果から、透過音レベルは、聞こえ 方、単語了解度の両者に対して、背景音レベル の大きい場合を除き強い相関を示すことが明ら かになった。また、透過音レベルが同じでも、 背景音レベルにより主観評価量が異なり、背景 音レベルをパラメータとした実験式をみると、 単語了解度で背景音レベルが特に大きい場合を 除けば、回帰直線は平行に近い傾向を示した。 このことは、透過音レベルと背景音レベルとの 差と主観評価量とが何らかの関係を示すことを 示唆している。したがって、検討ாでは、透過 音レベルと背景音レベルとの差を指標として実 験結果を整理し考察する。また、室内の吸音条 件の影響についても検討する。

\section{1 透過音レベルと背景音レベルとの差と聞こ え方}

透過音レベルと背景音レベルとの差の值を指 標として、その值と聞こえ方のグレードとの関 係を図 8 に示した。この図から次のことがわ

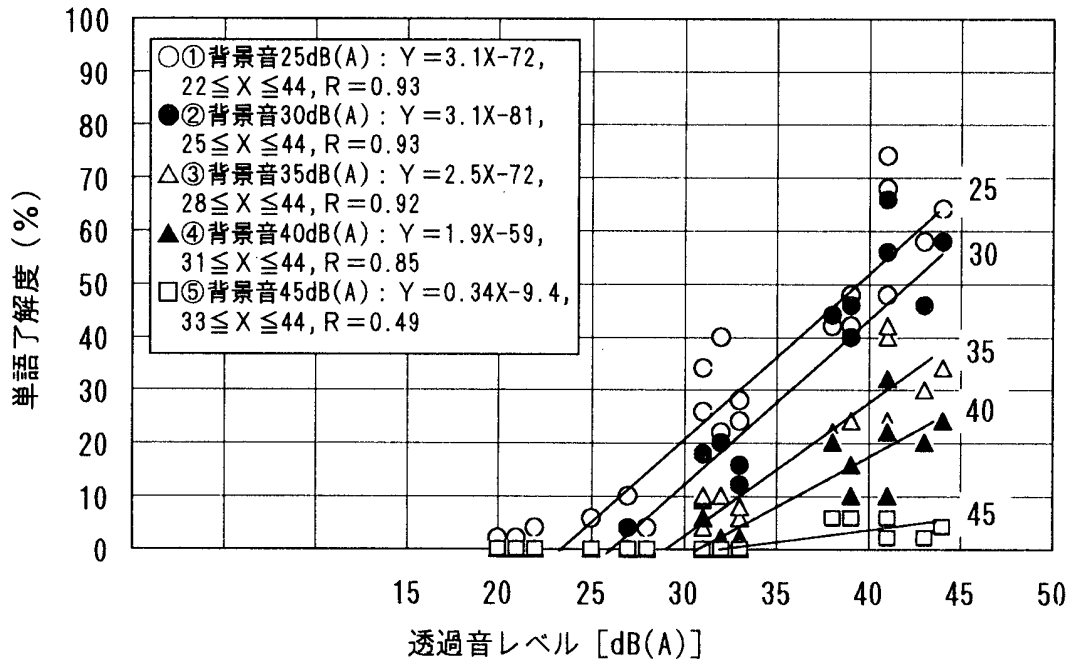

図 7 透過音レベルと単語了解度

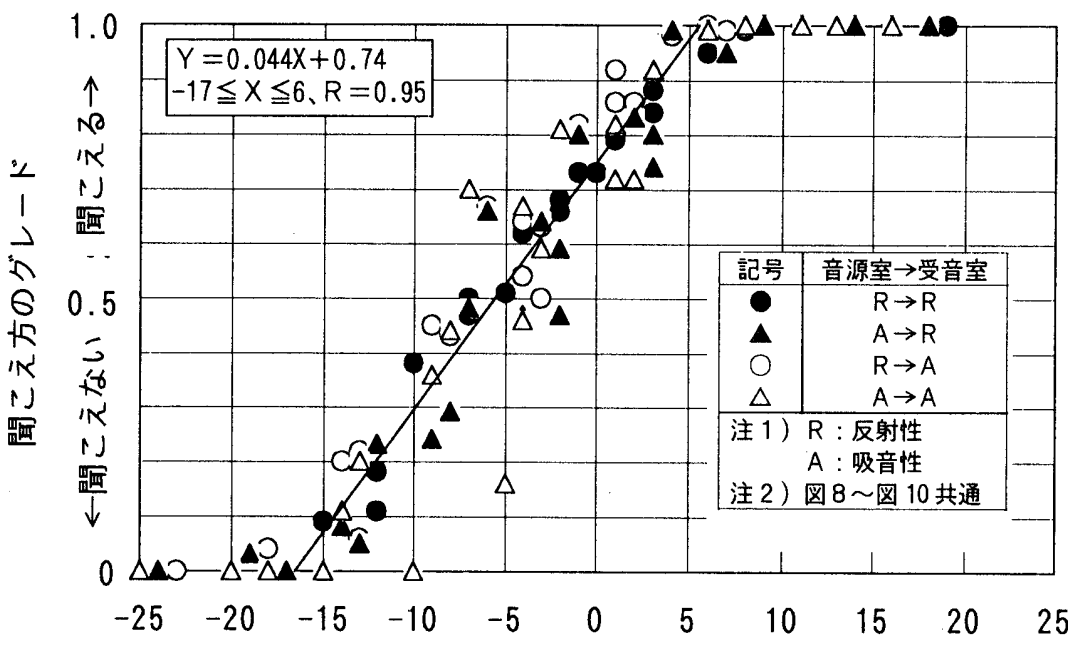

世透過音小

透過音レベルー背景音レベル $[\mathrm{dB}]$

透過音大 $\rightarrow$

図8＼cjkstart透過音レベルと背景音レベルとの差と

聞こえ方のグレード

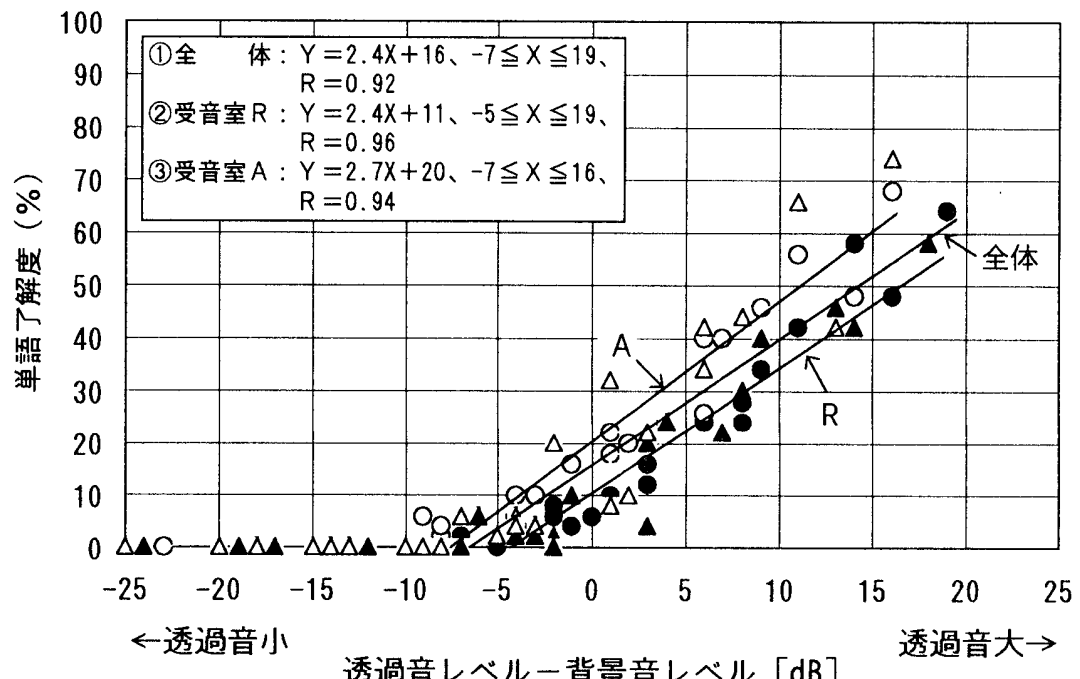

図 9 透過音レベルと背景音レベルとの差と単語了解度 
かった。

(1) 透過音レベルと背景音レベルとの差がー $17 \mathrm{~dB}$ から+6 dBの範囲では相関係数は0.95を示し た。

(2) 差が+6 dB以上では「聞こえる」という回答 がほとんどを占め、ー $6 \mathrm{~dB}$ 付近では「かすかに 聞こえる」という回答が多く、ー $17 \mathrm{~dB}$ 以下では 「聞こえない」という回答がほとんどを占め た。

(3) 回答が回帰直線よりも「聞こえない」側に大 きく外れている值は、透過音のレベルが $20 \mathrm{~dB}(\mathrm{~A})$ の場合であり、このようにレベルの小さいとき には、背景音レベルとの差の值のみでは説明で きなく、別途検討する必要がある。

(4)音源室、受音室の吸音条件による違いはみら れなかった。

\section{2 透過音レベルと背景音レペルとの差と単語了解度}

透過音レベルと背景音レベルとの差の值と単語了解度との関係 を図 9 に示した。この図から次のことがかかった。

(1) 透過音レベルと背景音レベルとの差がー $7 \mathrm{~dB}$ から $+19 \mathrm{~dB}$ 範 囲では相関係数は 0.92 を示した。

(2) 受音室が反射性の場合と吸音性の場合とでは、後者の方が単 語了解度が大きい值を示した。ただし、音源室の吸音条件による 違いはみられなかった。

(3) 意味がわからなくなる領域は、レベル差が受音室が吸音性の 場合でー $7 \mathrm{~dB}$ 以下、反射性の場合でー $5 \mathrm{~dB}$ 以下であった。

透過音レベルと背景音レベルの差と主钼評価量が強い相関を示 した理由としては次のようなことが考えられる。

表 1 の透過音特性パターンに透過音と背景音の周波数特性パ ターンを示したように、背景音レベルを上下させることにより、 帯域毎の透過音のオクターブバンドレベルと背景音のオクターフ バンドレベルとのレベル差は変化する。このとき、前者が後者を 上回る帯域数が、250Hz帯域を卓越周波数帯域として增減すること がかる（背景音レベルを上げると、全ての帯域で透過音レベル が背景音レベルを下回る場合もある）。

今回、透過音のレベルの絶対值だけでなく、このようなレベル 差についても調べたわけであるが、実験結果は、透過音のレベル と背景音のレベルとの相対的な関係が主観評価に影響を与えるこ とを示したといえる。すなわち、被験者は、主として、透過音の レベルと背景音のレベルの「差」を重要な判断項目の 1 つとして いるものと推察される。

\section{3 聞こえ方と単語了解度}

聞こえ方のグレードと単語了解度との関係を図10に示した。こ の図から次のことがわかった。

(1) 聞こえ方のグレードが、0.4以上 1.0 未渵の範囲では相関係数 が0.82を示した。
(2) 聞こえ方のグレードが1.0で、単語了解度の巾が50\%にも及ん でいるのは、グレードの尺度化に問題があり、実際には「聞こえ る」のグレードをさらに細分化するなどの必要があったことを示 唆している。

(3) 聞こえ方のグレードが 0.8 以上になると、単語了解度は $10 \%$ 以 上を示した。

(4) 聞こえ方のグレードが0.4以下では、意味がわからない領域と なった。

(5) 受音室が反射性の場合と吸音性の場合では、わずかではあるが 後者の方が単語了解度が大きい値を示した。たたし、音源室の吸 音条件による違いはみられなかった。

聞こえ方のグレードと笚語了解度との関係については、前述の ように、聞こえ方のグレードの尺度化の問題があるが、聞こえ方 のグレードが0.5（かすかに聞こえる）付近を境として、それより 上のグレードでは意味がわかる場合が多くなるなどのおおよその 傾向を把えることはできたと考えている。

\section{5.まとめ}

本報では、背景音レベル別に、室間平均音圧レベル差・透過音 レベルと主観評価量との関係を調べた結果、次のことがわかっ た。

(1) 室間平均音圧レベル差から求めた D 数よりも、透過音レベル の方が主観評価量と強い相関を示した。

(2) 透過音レベルと背景音レベルとの差の值と主観評価量は、” 定の範囲内で、強い相関を示した。

(3) 聞こえ方のグレードと単語了解度との関係については、グ レードの尺度化の問題はあるが、おおよその傾向を示した。

今回の結果は、基礎的な検討段階でのものであり、今後検討す べき課題が多く残されている。検討課題としては、透過音レベル が特に小さいときと背景音レベルが特に大きくなったときに、主 観評価量との対応がよくなかったが、この理由の解明などが挙げ 
られる。また、特に、今回のような実験室での実験結果と実際の 生活実感との関連を検討することが重要事項であろう。さらに、 音量感、音質感、不快感との関係の㭘討、情報理論の適用の検 討、室内音響の分野で、話し声の了解度を表す指標の一つとして 使われているMTI・STIを適用する方法7),8)の検討なども大切である と考えている。

\section{謝辞}

本実験に貴重なこ助言を戴いた干葉工業大学 子安 勝教授に謝 意を表します。

$<$ 注 $>$

注 1 ) 主観評価実験システム: 遮音設計では、对象騒音から界壁・サッシなど の遮音構造を透過し、受音点に到達した騒音のレベルを予测する。本シス テムは、この結果を実音化し、無響室において主観的評価を行なうことに より、各種遮音蔧造の選定に役立てることを目的として作成されたものて ある。今回、このシステムを音声の透週音の主観評価実験に適用した。な お、このシステムでは、無響室の受聴点のオクターブパンドレベルを管理 すれば、任意のドライソースと、任意の「音源 $\rightarrow$ 遮音構造 $\rightarrow$ 受音点」のイ ンパルスレスポンスを組合わせて試聴することが可能である。

注 2) 本諭文は、参考文献 7）、8）に新たな研究結果を加え、加筆修正した ものである。
<参考文献>

1）加藤雅裕、杉野潔：被験者の経験が明瞭度試験におよぼす影響に関する検 討、日本音響学会講演諭文集、PP.933〜934,1994.10～11

2) 橋本修、木村翔: 会話音声の発生レートの頻度を考虑した三連音節明睹度 試験用音源の检討、日本音響学会建築音響研究会資料AA93-47、PP.1 7、 1993.10

3) 戸井田義徳：これまでに製作された明瞭度測定用音源の調查と分析、日本 建勧学会環境工学委員会音環境運営委員会室内音響小委員会資料、日本音 響学会建筑音翌研究会資料、資料番号AA-94-13、PP. 1 8、1994.3

4 ）佐藤洋、長坂宗重、吉野博、佐藤隆 : 文章音表を用いた残響・騒音の音声 聴取に及ほす影響の評価に関する研究、日本建築学会計画系諭文集、No. 495、PP.15 20、1997.5

5 ）宮尾健一：テレビ、人声の発生音、音翌技術No.94,PP.33〜36,1996.6

6 ）（社）日本音響材料協会編：騒音・振動対策ハンドブック（測定:NHK技術 研究所)、P.560, 1982 .

7）宮尾健一、大川平一郎、山崎芳男：透過音の評価に関する実験的研究一第 1 報 透過音の単語了解度による評価一、日本建築学会大会学術講演梗概 集、PP.257 258, 1995.8

$8 ）$ 宮尾健一、大川平一郎、山崎芳男：透過音の評価に関する実験的研究一第 2 報 透過音の単語了解度による評価 (2) 一、日本建築学会大会学術講演 梗概集、PP.35 36,1996.9

（1997年 9 月 10 日原稿受理， 1998 年 4 月 7 日採用決定) 